\title{
UDZIAŁ WYKŁADOWCY I STUDENTÓW W ELIMINOWANIU BLĘDÓW JĘZYKOWYCH NA ZAJĘCIACH Z NIEMIECKO-POLSKICH TEUMACZEŃ USTNYCH
}

\begin{abstract}
Słowa kluczowe: dbałość o poprawność językową, eliminowanie błędów językowych, niemiecko-polskie thumaczenia ustne, optymalizacja poprawności tłumaczenia

Streszczenie. W niniejszym artykule podejmuję próbę optymalizacji metod eliminowania błędów językowych, jakie popełniane są najczęściej przez studentów germanistyki na zajęciach z niemiecko-polskich tłumaczeń ustnych. Przedstawione tu propozycje bazują na moim wieloletnim doświadczeniu zawodowym nauczyciela akademickiego oraz tłumacza. W procesie korygowania błędów językowych staram się na bieżąco zwracać uwagę studentów na błędy językowe, jakie popełniają oni w trakcie prowadzonych przeze mnie zajęć tłumaczeniowych. Nie koryguję jednak ich błędów sama, lecz angażuję do tej korekty przede wszystkim samych studentów, gdyż uważam, że tylko w ten sposób mogą oni zyskać pełną świadomość popełnianych przez siebie błędów. Ma to bowiem według mnie bardzo istotne znaczenie w dążeniu do optymalizacji poprawności tłumaczenia oraz w dbałości o poprawność językową, tym bardziej że studenci popełniają błędy niestety także w języku polskim, który dla przeważającej większości jest językiem ojczystym.
\end{abstract}

Błąd językowy, podobnie zresztą jak każdy inny rodzaj błędu, jest w zasadzie immanentnym elementem życia ludzkiego. Każdy z nas nieustannie popełnia w życiu jakieś błędy, gdyż - jak mówi nam znane łacińskie przysłowie - „errare humanum est". Jednak to nie samo popełnianie błędów jest tak naprawdę problemem, lecz ich niedostrzeganie lub ignorowanie bądź też nieustanne powtarzanie. Dlatego też konieczne jest nie tyle piętnowanie kogoś za popełniony błąd, ile w pierwszym rzędzie uświadomienie istoty owego błędu, a następnie konsekwentne dążenie do jego eliminacji w przyszłości. Metodę tę odnieść można również do błędów językowych popełnianych przez studentów germanistyki na zajęciach z niemiecko-polskich tłumaczeń ustnych, co ukazane zostanie w niniejszym artykule.

${ }^{1}$ finew@univ.gda.pl; Katedra Językoznawstwa i Teorii Przekładu, Instytut Filologii Germańskiej, Wydział Neofilologiczny, Uniwersytet Gdański, 80-952 Gdańsk, ul. Wita Stwosza 51. 
Zarysowana powyżej tematyka metodologiczna warunkuje sposób omówienia badanego problemu. Po zdefiniowaniu błędu językowego (pkt 1) i scharakteryzowaniu jego rodzajów (pkt 2) przedstawione zostaną metody eliminacji błędów językowych na zajęciach z tłumaczeń ustnych ze szczególnym uwzględnieniem stopnia zaangażowania wykładowcy i studentów w uświadamianie konieczności i zasad wprowadzania obligatoryjnych bądź fakultatywnych zmian językowych podczas procesu tłumaczenia w celu osiągnięcia optymalnej poprawności językowej (pkt 3.1) oraz w korygowanie błędów popełnianych już w trakcie tłumaczenia (pkt 3.2).

\section{O ISTOCIE BLĘDU JĘZYKOWEGO}

Błąd językowy rozumiany jest jako „niezamierzone przez mówiącego odchylenie (dewiacja) od reguł przewidzianych przez system danego języka lub od obowiązującej w ramach tego systemu normy językowej" (Szulc 1994, s. 40). Z podanej definicji wynika dobitnie, iż poprawność językowa odnoszona jest zawsze do jakiejś ściśle określonej normy językowej, na którą składa się ,zbiór środków językowych uznanych przez daną wspólnotę językową za poprawne" (ibidem, s. 154). Norma językowa determinuje poprawność systemową (norma intrakodalna lub systemowa) bądź poprawność użycia języka $\mathrm{w}$ danym akcie komunikacyjnym (norma ekstrakodalna lub pragmalingwistyczna) oraz typologię błędów językowych (por. pkt 2). Niekiedy dana norma językowa przenoszona jest do innego języka lub na inne obszary tego samego języka. Transfer ten może mieć charakter pozytywny i wspomagać naukę innego języka bądź proces tłumaczenia lub też negatywny, gdy generuje błędy interferencyjne (Bawej 2010, Wojaczek 2007a, Wojaczek 2007b) w wyniku niewłaściwego zwiększenia zakresu normy w określonym języku (interferencja intralingwalna lub wewnątrzjęzykowa), stosowania normy poprawnej wyłącznie dla danego języka w innym języku (interferencja interlingwalna lub międzyjęzykowa) bądź nieadekwatnego w stosunku do sytuacji doboru poprawnych form językowych (interferencja glottopragmatyczna).

Garczyński (1973, 1981, 1990) upatruje źródeł błędów językowych w uwarunkowaniach zewnętrznych (np. w okolicznościach stresowych, wpływie czynników społecznych, sposobie wysławiania się innych osób itp.) lub też wewnętrznych (np. w różnego rodzaju zaburzeniach, typie psychicznym, lenistwie, konserwatyzmie, lękach, niewłaściwych oczekiwaniach i złym nastawieniu do języka). Dla poprawności językowej bardzo istotny jest również sposób przyswajania języka i jego norm. Błędy językowe wynikają bowiem często także $\mathrm{z}$ wyboru fałszywych metod nauki języka 
(obcego), braku stosownych informacji, ignorancji, zapominania, błędnych skojarzeń, niedostrzegania różnic, pochopnych uogólnień i braku kontroli językowej.

\section{TYPOLOGIA BLĘDÓW JĘZYKOWYCH}

Najbardziej rozpowszechniona, klasyczna typologia błędów językowych opiera się na obu rodzajach norm wyróżnianych przy definiowaniu błędu językowego (por. pkt 1) oraz na tradycyjnych płaszczyznach językowych. Wśród błędów językowych można zatem wyróżnić następujące ich rodzaje (Dubisz 1998):

1. błędy zewnątrzjęzykowe (zapisu)

1.1. ortograficzne

1.2. interpunkcyjne

1.3. graficzne

2. btędy wewnątrzjęzykowe

2.1. systemowe (językowe)

2.1.1. gramatyczne (fleksyjne, sktadniowe)

2.1.2. fonetyczne (wymowa, akcent)

2.1.3. leksykalne (stownikowe, frazeologiczne, stowotwórcze)

2.2. stylistyczne (użycia)

Podziału błędów językowych dokonuje się również w oparciu o następujące kryteria (Garczyński 1973):

1. kryterium czasu:

1.1. błędy jednorazowe (chwilowe)

1.2. btędy powtarzajace się (trwate)

2. zakres przedmiotowy:

2.1. blędy formalne (teoretyczne, poznawcze)

2.2. błędy rzeczowe (praktyczne, działania)

3. zakres podmiotowy:

3.1. btędy indywidualne

3.2. btędy zbiorowe

4. skutki popełnienia błędu:

4.1. btędy pożyteczne

4.2. błędy nieszkodliwe

4.3. błędy szkodliwe 


\section{METODY ELIMINACJI BLĘDÓW JEZZYKOWYCH W PROCESIE TLUMACZEŃ USTNYCH ZE SZCZEGÓLNYM UWZGLĘDNIENIEM STOPNIA ZAANGAŻOWANIA WYKLADOWCY I STUDENTÓW}

Metodycy nauczania języków obcych zastanawiają się na ogół nad momentem, w którym należy dokonywać korekty błędów językowych (m.in. Nerlicki 2009), jak również nad jej formą bądź częstotliwością. O jej konieczności nie trzeba bowiem z pewnością nikogo przekonywać, gdyż jest powszechnie wiadomo, że nieuświadomione bądź niepoprawiane błędy prowadzą z czasem do utrwalenia się ich u studenta (bądź jakiegokolwiek innego ucznia) w postaci złego nawyku, który jest później niezmiernie trudny, a czasami wręcz niemożliwy do wyeliminowania. Przy takim założeniu konieczne jest więc w dydaktyce tłumaczeniowej uświadomienie studentom podstawowych różnic między thumaczonymi językami jeszcze przed rozpoczęciem procesu tłumaczenia (pkt 3.1). W trakcie thumaczenia wskazana jest natomiast dalsza ciągła (samo)kontrola poprawności językowej zarówno ze strony wykładowcy, jak i studentów (pkt 3.2). Wykładowca powinien jednak na każdym etapie eliminacji błędów odgrywać rolę osoby jedynie naprowadzającej studenta na popełniony błąd, czyniąc to jednocześnie w bardzo wyważony sposób. Zadaniem studenta jest bowiem samodzielna poprawa swojego błędu i wyjaśnienie jego przyczyny, gdyż „błąd, który pedagog tylko zaznaczył, a uczeń sam poprawił, ma mniej szans powtórzenia się niż błąd poprawiony przez nauczyciela. Jeszcze lepiej, gdy uczeń zrozumie, a nawet objaśni, dlaczego popełnił błąd [...]. W żadnym wypadku nie wolno dopuścić do tego, by uczeń, nie mogąc sprostać wymaganiom nauczyciela, stracił wiarę w swe możliwości i zniechęcił się do przedmiotu." (Garczyński 1973, s. 258)

W przypadku problemów studenta z identyfikacją błędu bardzo pomocna okazuje się aktywność innych studentów, którzy zobligowani są przez wykładowcę do koncentracji na poprawności językowej w trakcie przysłuchania się wypowiedziom kolegów czy koleżanek z tej samej grupy ćwiczeniowej (por. pkt 3.2). W ten sposób w proces eliminacji błędów włączone są wszystkie osoby w danej grupie, co pozwala znacznie zintensyfikować pracę studentów na zajęciach, a przede wszystkim skłonić ich do ciągłej czujności językowej, która powinna cechować każdego dobrego tłumacza.

\subsection{UŚWIADOMIENIE KONIECZNOŚCI WPROWADZANIA ZMIAN JĘZYKOWYCH W PROCESIE TŁUMACZENIA}

Przed przystąpieniem do jakiegokolwiek rodzaju tłumaczenia nieodzowne staje się odpowiednie przygotowanie studentów do tego procesu, które polega w pierwszym rzędzie na uświadomieniu różnic między normami danych języków, 
a tym samym konieczności wprowadzania zmian językowych podczas tłumaczenia (Wojaczek 2006). Skłonność do tłumaczenia w sposób dosłowny, a więc do transferu norm jednego języka do innego, jest bowiem jedną z najsilniejszych tendencji thumaczeniowych, która wynika zapewne z ludzkiej wygody i lenistwa, lecz prowadzi do poważnych błędów interferencyjnych (por. pkt 1). Co ciekawe, w toku wieloletniej nauki języka obcego błędy takie zdarzają się także w języku ojczystym.

Wobec powyższych faktów konieczne jest najpierw bardzo wnikliwe omówienie różnic obu porównywanych języków pod kątem możliwych interferencji językowych (por. pkt 1). Służyć temu może analiza następujących niemieckich przykładów oraz ich polskich ekwiwalentów thumaczeniowych (por. 1a-8c) ${ }^{2}$ : 1.

a) ein Lebenszeichen geben $=>$ dać znak życia

b) Ich fahre zur Mutter. $=>$ Jadę do matki.

c) Jadę do matki. $=>$ Ich fahre zur Mutter.

2.

a) Iran $=>$ Iran

b) Anna $=>$ Anna

c) Europa $=>$ Europa

3 .

a) Ball $=>$ bal

b) Schulz $=>$ Szulc

c) Marsch $=>$ marsz

4 .

a) Barrabas $=>$ Barabasz

b) Affront $=>$ afront

c) Astronom $=>$ astronom

5 .

a) Holzstich $=>$ drzeworyt

b) Fisch will schwimmen. $=>$ Ryb(k)a lubi pływać.

c) keinen Laut von sich geben $=>$ nie pisnąć ani słówka

6.

a) Dummkopf $=>$ głupiec

b) Wanderungsbewegungen $=>$ ruchy migracyjne

c) bekanntlich $=>$ jak wiadomo

7 .

a) neben $\mathrm{mir}=>$ oprócz mnie

b) nach $1990=>$ po roku 1990

c) od roku $1990=>$ seit 1990

${ }^{2}$ Jedynie w dwóch wypadkach (2c, 7c) językiem wyjściowym jest wyjątkowo język polski, a docelowym język niemiecki. 
8.

a) Man sagte, daß... $=>$ Zostało powiedziane, że ...

b) Kleider, die mir gefallen $=>$ podobające mi się ubrania

c) polnische Bevölkerung $=>$ Polacy

Zadanie studentów sprowadza się wówczas do samodzielnego wskazania w każdym z powyższych przykładów zmian językowych, których dokonano w trakcie tłumaczenia, określenia ich rodzaju i przyczyny, a więc podania także odpowiedniej normy językowej, jak również do wyjaśnienia powodów dodania lub opuszczenia pewnych elementów języka wyjściowego w tłumaczeniu na język docelowy. Ogromnie pomocne jest przy tym sporządzenie przez studentów listy możliwie dosłownych ekwiwalentów tłumaczeniowych $\mathrm{w}$ analizowanych przykładach (por. 1a'-8c') w celu lepszego uwidocznienia różnic językowych i zmian thumaczeniowych:

1.

a') * życiaznak dać / * życia znak dać

b') Ja jadę do matki.

c') * Fahre zur Mutter.

2.

a') [ịrãn] / * [ira:n] / * [irãnn]

b') [a्anna] / * [anna]

c') [europa] / * [euro:pa] / * [oyro:pa] / * [oyropa]

3 .

a') $\mathrm{Bal} / \mathrm{bal} / *$ Ball / * ball

b') Szulc / * Schulz / * Schulc / * Szulz

c') Marsz / marsz / * Marsch / * marsch

4.

a') Barabasz [barabaf] / * Barabasz [bara:baf] / * Barabasz [barabaf] / * Barrabas [barabas] / * Barrabas [barabas] / * Barrabas [bara:bas] / Barabas [barabas] / * Barabas [ba:rabas] /

* Barabas [barabas] / * Barabas [bara:bas] / * Barrabasz [barabaf] / * Barrabasz [bara:baf] /

* Barrabasz [barabaf]

b') Afront [âfrõnt] / afront [affrõnt] / * Afront [afrōnt] / * afront [afrõnt] / * Affront [afrōnt] /

* affront [afrōnt] / * Affront [âfrõnt] / * affront [âfrõnt]

c') Astronom [astrōnõm] / astronom [astrōnõm] / * Astronom [astrõ:nõm] /

* astronom [astrõ:nõm] / * Astronom [astrõnõ:m] / * astronom [astrõnõo:m]

5 .

a') * drewnoukłucie / * ukłucie drewna

b') Ryba chce pływać.

c') * żaden dźwięk od siebie dać / * nie dać od siebie żadnego dźwięku 
6.

a') * głupiagłowa / głupia głowa

b') * wędrówkiruchy / * ruchy wędrówkowe

c') * znanie / *znajomo

7.

a') obok mnie

b') po 1990

c') seit dem Jahre 1990

8.

a') Powiedziano, że ...

b') ubrania, które mi się podobają

c') polska ludność

Liczba podawanych przez studentów ekwiwalentów zależy każdorazowo od stopnia znajomości norm obu porównywanych języków. Konstrukcje całkowicie niepoprawne językowo oznaczane są jednocześnie gwiazdką, różnice w wymowie przedstawiane są $\mathrm{w}$ nawiasach kwadratowych, a różnice $\mathrm{w}$ akcencie zaznaczane dodatkowo za pomocą kreski pod akcentowaną samogłoską (por. 2a'-c', $\left.4 a^{\prime}-c^{\prime}\right)$. Po porównaniu wyjściowych przykładów (por. 1a-8c) z utworzonymi później opcjami tłumaczeniowymi (por. 1a'-8c') studenci przygotowują listę dostrzeżonych przez siebie obligatoryjnych i fakultatywnych zmian językowych w analizowanych przykładach, wytłuszczając je w druku, określając samodzielnie ich rodzaj i wpisując ich nazwę obok cyfr szeregujących poszczególne grupy zmian językowych (por. 1a"-8c"). Akceptowalne językowo tłumaczenia dosłowne prezentowane są $\mathrm{w}$ nawiasach okrągłych obok ekwiwalentu thumaczeniowego zaproponowanego już na początku analizy (por. 1a-8c):

1. zmiany gramatyczne

a") ein Lebenszeichen geben $=>$ dać znak życia

b") Ich fahre zur Mutter. => (-) Jadę do matki. (Ja jadę do matki.)

c") Jadę do matki. $=>$ Ich fahre zur Mutter.

2. zmiany fonetyczne

a") Iran [irạ:n] => Iran [ị̂ãn]

b") Anna [ạna] => Anna [ã̃nna]

c") Europa [oyro:pa] => Europa [europa]

3. zmiany ortograficzne

a") Ball $[$ ball $]=>$ bal (Bâl) $[$ ball $]$

b") Schulz $[f \underline{u}$ lts $]=>$ Szulc $[f \underline{u}$ lts $]$

c") Marsch $[\operatorname{mar} f]=>\operatorname{marsz}($ Marsz) $[\operatorname{mar} f]$

4. zmiany ortograficzno-fonetyczne

a") Barrabas [barabas] => Barabasz [barabaf $]$

b") Affront [afrōnt] => afront (Afront) [a a frõnt]

c") Astronom [astrono:m] => astronom (Astronom) [astrōnõm] 
5. zmiany leksykalne

a") Holzstich => drzeworyt

b") Fisch will schwimmen. => Ryb(k)a lubi pływać. (Ryba chce pływać.)

c") keinen Laut von sich geben $=>$ nie pisnąć ani słówka

6. zmiany leksykalno-gramatyczne

a") Dummkopf $=>$ glupiec (głupia glowa)

b") Wanderungsbewegungen $=>$ ruchy migracyjne

c") bekanntlich $=>$ jak wiadomo

7. zmiany stylistyczne

a") neben mir $=>$ oprócz mnie (obok mnie)

b") nach $1990=>$ po roku 1990 (po 1990)

c") od roku 1990 => seit (-) 1990 (seit dem Jahre 1990)

8. zmiany stylistyczno-gramatyczne

a") Man sagte, daß... => Zostało powiedziane, że ... (Powiedziano, że ...)

b") Kleider, die mir gefallen => podobające mi się ubrania (ubrania, które mi się podobają)

c") polnische Bevölkerung => Polacy (polska ludność)

$\mathrm{W}$ trakcie analizowania ostatniej grupy przykładów (por. 1a"-8c") studenci samodzielnie określają i wyjaśniają także różnice niemieckich i polskich norm językowych, które wymuszają ściśle określone zmiany językowe w procesie thumaczenia (por.1a-8c). Normy fonetyczne i (orto)graficzne dotyczą głównie internacjonalizmów i zapożyczeń, normy leksykalne - idiomów i stałych związków frazeologicznych, normy stylistyczne natomiast tzw. „wolnych przekładów"3.

1) normy gramatyczne

Charakterystycznym dla języka niemieckiego zbitkom językowym odpowiadają na ogół zestawienia słów w języku polskim (1a", 6b"), który jedynie w nielicznych przypadkach (5a") dopuszcza podobne złożenia.

Język niemiecki wymaga użycia zaimka osobowego w roli podmiotu w zdaniach oznajmujących, gdyż jego brak zmienia tryb zdania na rozkazujący (por. 1c'w załączniku nr 2). W języku polskim zaimek osobowy jest właściwie zbędny, gdyż na podmiot wskazują już same końcówki czasownika (1b"-c"). Użycie zaimka osobowego jest jednak możliwe, gdy służy on wyróżnieniu podmiotu w grupie osób (1b").

2) normy fonetyczne

Podczas gdy akcent w języku niemieckim pada najczęściej na pierwszą (2b", 4a") lub ostatnią sylabę (2a", 4b", 4c"), język polski odznacza się konsekwentnym akcentowaniem przedostatniej sylaby (2a"-c", 4a"-c").

${ }^{3}$ Ponieważ do błędów interferencyjnych dochodzi najczęściej wskutek ogromnej zbieżności fonetycznej, (orto)graficznej i semantycznej języków, trzy pierwsze z wymienionych wyżej norm wymagają szczególnej uwagi w nauczaniu języków obcych i tłumaczeniu (Wojaczek 2009). 
W języku niemieckim w akcentowanych sylabach występują z reguły długie samogłoski (2a", 2c", 4c"), których brak jest całkowicie w systemie fonetycznym języka polskiego. ${ }^{4}$

Różnice fonetyczne w obrębie obu języków dotyczą także wymowy podwojonych spółgłosek (2b", 4a", 4b") i dyftongów (2c").

3) normy (orto)graficzne

W języku niemieckim wszystkie rzeczowniki pisane są wielką literą, a w języku polskim wyłącznie nazwy własne (2a"-c", 3b", 4a"), natomiast rzeczowniki pospolite tylko wówczas, gdy stoją na początku zdania (3a", 3c", 4b"-c").

Określone tak samo brzmiące głoski zapisywane są w obu językach w zupełnie inny sposób (por. 3a"-c")

4) normy leksykalne

Za zmiany leksykalne w thumaczeniu (5a"-c", 6a"-c") odpowiedzialny jest przed wszystkim uzus językowy. Ekwiwalenty thumaczeniowe różnią się wówczas pod względem semantycznym całkowicie (5a", 5c", 6a", 6c") lub tylko częściowo (5b", 6b") od form wyjściowych. W nielicznych przypadkach możliwe jest wprawdzie również dosłowne tłumaczenie (5b", 6a"), lecz utworzone w ten sposób ekwiwalenty mają już niekiedy w języku docelowym nieco inne znaczenie niż w języku wyjściowym. Tłumaczenie tego rodzaju elementów językowych sprawia tłumaczom najwięcej problemów, gdyż są one specyficzne dla danego języka i tym samym nie podlegają żadnym z góry przewidywalnym regułom użycia językowego.

5) normy stylistyczne

Zmiany stylistyczne w thumaczeniu (7a"-c", 8a"-c") są najczęściej efektem wyboru przez thumacza jednego spośród kilku możliwych ekwiwalentów językowych. Są one zabiegiem stosowanym m.in. w przypadku niemożności znalezienia najtrafniejszego odpowiednika lub też $\mathrm{w}$ celu uniknięcia powtórzeń w tekście. Tłumacz nie zawsze ma jednak całkowitą dowolność w wyborze ekwiwalentu, gdyż jego decyzję warunkują nierzadko normy pragmalingwistyczne (por. pkt 1), związane np. z kontekstem wypowiedzi, rodzajem i stylistyką tekstu bądź języka.

\subsection{KORYGOWANIE BŁĘDÓW JĘZYKOWYCH POPEŁNIANYCH W NIEMIECKO-POLSKICH TŁUMACZENIACH USTNYCH}

Tłumaczenie ustne jest dużo trudniejsze od thumaczenia pisemnego z wielu powodów, które podyktowane są charakterem tego procesu (Wojaczek 2006). Oprócz trudności czysto językowych, które mogą pojawiać się w obu formach

${ }^{4}$ Samogłoski mogą być oczywiście wydłużane także w języku polskim (np. z pobudek ekspresyjnych), co znajduje jednak automatycznie odzwierciedlenie w innym zapisie graficznym odnośnego słowa (np. Ale duża ryba! versus Ale duuuża ryba!). 
thumaczenia, tłumacz ustny musi pokonać bowiem również dodatkowe przeszkody zakłócające jego pracę (np. rozpraszający uwagę hałas lub stres spowodowany bezpośrednim kontaktem z innymi ludźmi bądź niemożliwością korzystania $\mathrm{z}$ różnego rodzaju pomocy w postaci choćby słownika albo zapisu tekstu wypowiedzi). Owe czynniki zewnętrzne (por. pkt 1) utrudniają z pewnością pracę tłumacza i mogą znacznie zwiększać liczbę popełnianych przez niego błędów.

Naturalna konieczność dużo silniejszej koncentracji tłumacza ustnego na procesie thumaczenia prowadzi natomiast często do jego zwiększonej samokontroli językowej. Stąd też wielu studentów samodzielnie koryguje na bieżąco własne błędy podczas thumaczenia ustnego, o ile są ich oczywiście świadomi. Z drugiej jednak strony istnieje spore grono studentów, którzy nie próbują poprawiać własnych błędów tłumaczeniowych mimo ich świadomości, gdyż starają się w ten sposób ukryć fakt popełnienia błędu, licząc na słabą czujność językową słuchających ich osób. W tej sytuacji kontrola językowa i ingerencja osób trzecich (pozostałych studentów lub wykładowcy) jest wręcz niezbędna, gdyż przeciwdziała utrwalaniu się danego błędu nie tylko u samego thumacza, lecz także u innych studentów słyszących niepoprawną językowo wypowiedź.

$\mathrm{Z}$ uwagi na wspomnianą wcześniej trudność tłumaczenia ustnego nie jest wskazane dodatkowe utrudnianie tego procesu poprzez przerywanie jego ciągłości w celu dokonania korekty błędu zaraz po jego pojawieniu się. Dlatego też studenci przysłuchujący się tłumaczeniu w wykonaniu koleżanek bądź kolegów mają za zadanie zapisywać na kartce usłyszane błędy językowe. Błędy te wymieniane i omawiane są przez nich jednak dopiero po zakończeniu tłumaczenia. Osoba, która je popełniła (tłumacz bądź też np. któryś z mówców), proszona jest wówczas o podanie poprawnej formy językowej, a więc o dokonanie swoistej autokorekty, oraz o uargumentowanie decyzji poprzez wymienienie stosownej normy językowej, która warunkuje wybór takiej właśnie, a nie innej formy językowej (por. pkt 3.1). Zabieg ten służy z jednej strony sprawdzeniu u studenta znajomości reguł danego języka, z drugiej zaś wykształceniu u niego zdolności logicznego myślenia, które cechować powinno każdy proces nauczania (Kotarbiński 1970).

\section{PODSUMOWANIE}

Błędy językowe należą do tych zjawisk życia codziennego, z którymi każdy człowiek musi zmierzać się wielokrotnie niezależnie od liczby języków, jakimi włada. Wskutek interferencji wewnątrzjęzykowej bądź glottopragmatycznej lub też pod wpływem uwarunkowań zewnętrznych bądź wewnętrznych pojawią się one bowiem nawet u użytkowników języka ojczystego. Dużo częstsze są naturalnie błędy będące skutkiem interferencji międzyjęzykowej w procesie nauki języ- 
ków obcych lub thumaczeń. W obu przypadkach błędy, które same w sobie są zjawiskiem zdecydowanie negatywnym, mogą odgrywać w trakcie ich umiejętnego eliminowania nader pożyteczną rolę. Dzięki zaangażowaniu przez wykładowcę całej grupy ćwiczeniowej w proces korekty językowej na zajęciach z niemiecko-polskich tłumaczeń ustnych wszyscy studenci mobilizowani są do ciągłej (auto) korekty, czujności językowej oraz kształcenia umiejętności logicznego myślenia poprzez konieczność argumentowania swoich decyzji o wyborze danego ekwiwalentu tłumaczeniowego. Jest to jednak możliwe dopiero po wcześniejszym poznaniu norm omawianych języków oraz uświadomieniu sobie konieczności wprowadzania pewnych zmian językowych w procesie tłumaczenia. Rola wykładowcy na każdym etapie eliminacji błędów językowych powinna się przy tym sprowadzać do osoby jedynie naprowadzającej studenta w bardzo wyważony sposób na popełniony błąd.

\section{BIBLIOGRAFIA}

Bandura L., 1963, Zagadnienie błędów uczniowskich, Warszawa.

Bawej I., 2010, Błąd leksykalny jako skutek procesów interferencyjnych, Bydgoszcz.

Dubisz S. (red.), 1998, Nauka o języku dla polonistów, Warszawa.

Garczyński S., 1973, Błąd. Źródła. Unikanie, Warszawa.

Garczyński S., 1981, Skąd te błędy, Warszawa.

Garczyński S., 1990, Strzeż się tych błędów, Warszawa.

Kołodziejek E., 2014, Walczymy z bykami, Warszawa.

Korzeniewska-Rogalewicz J., 1986, Btad leksykalny a dydaktyka języka obcego. Na materiale języka rosyjskiego, Warszawa.

Kotarbiński T., 1970, Sprawność i błą, Warszawa.

Nerlicki K., 2009, Der Zeitpunkt der Fehlerkorrektur und seine Auswirkungen auf die mündliche Sprachproduktion polnischer Deutschlehrer, w: H. Breuer i in. (red.), Spracherwerbsforschung im Spannungsfeld von Angewandter Linguistik und Pädagogik, Berlin, s. 106-121.

Szulc A., 1994, Słownik dydaktyki języków obcych, Warszawa.

Wojaczek E., 2006, Metody przygotowania studentów do tlumaczeń pisemnych i ustnych na pierwszym roku studiów germanistycznych, w: J. Beksiński (red.), Glottodydaktyczne implikacje we współczesnych badaniach germanistycznych, Włocławek, s. 137-148.

Wojaczek E., 2007a, Der Grad der Interferenz im multilingualen Sprachunterricht und deren Vorbeugungsmethoden, w: A. Szeluga (red.), Neue Tendenzen und Perspektiven des Fachs Deutsch als Fremdsprache am Anfang des XXI. Jahrhunderts, Piła, s. 57-72.

Wojaczek E., 2007b, Der positive und negative (= die Interferenz) Transfer bei der Übersetzung und dem Fremdsprachenerwerb, w: J. Wiśniewski (red.), W dialogu języków i kultur, Warszawa, s. 279-286.

Wojaczek E., 2009, Internacjonalizmy, przysłowia, idiomy oraz gra słów jako czynniki kulturowe w nauczaniu języków obcych i przekładzie, a globalizacja komunikacji językowej, w: J. Kortas (red.), La Globalisation Communicationnelle Enrichissement et Menace pour les langues, Gdańsk, s. 391-399.

http://pl.wikipedia.org/wiki/Błąd_językowy [ 08.04.2015] 


\section{Ewa Wojaczek}

\section{THE TEACHER AND STUDENTS CONTRIBUTION TO THE ELIMINATION OF LANGUAGE MISTAKES DURING GERMAN-POLISH INTERPRETING CLASSES}

Keywords: attention to language correctness, elimination of language mistakes, German-Polish interpreting, optimization of correctness of translation

Summary. In the paper, I attempt to optimize the elimination techniques of the most frequent language mistakes made by students of German studies during German-Polish interpreting classes. The suggestions which are presented in the paper are based on my long professional experience as an university teacher and a translator. In the process of the error correction, I systematically try to draw students' attention to the mistakes they make during my translation classes. I do not correct the mistakes myself but I involve the students in the correction process, because I think that only in such a way they can be fully aware of the mistakes they make. I believe such awareness helps optimize the correctness of translation and supports the attention to language correctness, especially that the students also make mistakes in the Polish language which is, after all, the native language for most them. 